\title{
Using Content and Language Integrated Learning to Develop Primary Official Language School Pupils' EFL Speaking Skills and their Motivation to Learn
}

\author{
Dr. Marwa Mourad Saleh*
}

\begin{abstract}
The present study aimed at developing primary official language school pupils' EFL speaking skills through the use of content and language integrated learning (CLIL). Participants of the study were 70 fifth year Defino primary official language school pupils at Fayoum governorate. They were divided into two groups; experimental and control 30 pupils each. The researcher prepared an EFL speaking skills test, an EFL speaking rubric, a motivation scale and a teacher's guide. Having pre administered the speaking skills test, the motivation scale and taught the experimental group using CLIL, the participants were post administered the same instruments. The results showed that the use of content and language integrated learning proved to be effective in developing primary official language school pupils' EFL speaking skills and their motivation to learn. The study concluded with some recommendations and suggestions for the pupils, teachers and curriculum designers. Also, suggestions for further research were provided.
\end{abstract}

Keywords: content and language integrated learning, EFL speaking skills, motivation, primary official language school pupils

\section{$1.1 \quad$ Introduction}

Language is first and foremost spoken and not written only. It is primarily speech. A large number of languages in the world are only spoken with no writing script. Also, several languages use their spoken forms more than the written ones. Speaking is a major skill for both communication and language learning. English teaching and learning in the classroom occurs through meaningful interaction that involves both the teacher and pupils. Teachers should encourage students to participate in classroom activities and initiate speech to express their ideas and feelings rather than becoming only respondents to teachers' questions.

Motivation is one of the essential key factors that affect language learning. Motivated EFL learners simply participate in an activity for the pleasure of learning the foreign language and the culture of its community. They are more likely to continue their studies than demotivated learners. Motivation is usually associated with high educational achievement and 
used to refer to successful learners. Without sufficient motivation, learners may encounter some difficulties in language learning (Alizadeh , 2016). Most pupils are not motivated to speak in a language that is alien/ foreign to them. They refrain from speaking lest they may make mistakes that make other pupils laugh and ridicule them.

Content and Language Integrated Learning (CLIL) is an educational approach to learning that aims to help students learn content through using a foreign or second language (Sulistova, 2013). Thus, CLIL classrooms are not typical language classrooms due to the fact that language is the medium through which content is transported. Non-linguistic content is used to teach a language and learners acquire new knowledge but in a foreign language. (Papaja \& Rojczyk, 2013). CLIL provides learners with a meaningful context for authentic communication around relevant and cognitively challenging content ( Sabra, 2017).

\subsection{Context of the problem}

Many EFL supervisors and teachers complain that pupils speak at the word level not at the sentence level. They take long time to compose utterances. Their spoken English language does not sound natural. Most of them are passive, shy and they do not like to participate in classroom activities. They avoid speaking up or taking risk for fear of making mistakes and being criticized by their classmates. This is supported by several studies some of which are Rao (2019) and Imane (2016).

The former confirmed that speaking skill is difficult because learners have to produce sentences on the spur of the moment. Also, most of learners do not have a sufficient amount of vocabulary or adequate knowledge of grammatical structures. The latter stated some factors that cause speaking difficulties to EFL learners: lack of exposure to authentic English language environment, practice and self confidence.

To document the problem, the researcher conducted a pilot study on 20 pupils from fifth year pupils enrolled in Defino primary official language school. The pilot study consisted of a speaking test where pupils were asked to describe a picture and to act out two mini dialogues. The results of the pilot study revealed that the majority $(75 \%)$ have poor speaking skills and they lack the ability to speak fluently or accurately. Also, the researcher administered a short motivation scale. The pupils' responses reflected their poor motivation in speaking class.

\subsection{Statement of the problem}

Despite its importance, speaking skill is overlooked and neglected in teaching EFL. Several primary official language school pupils lack several speaking skills that help them express their ideas, opinions and feelings fluently. Moreover, they are not totally motivated to learn. That is why the present study attempted to help them develop their speaking skills and motivation to learn through using content and language integrated learning (CLIL). 


\subsection{Questions of the study}

The main question could be stated as follows:

How can content and language integrated learning (CLIL) be used to develop primary official language school pupils' EFL speaking skills and their motivation to learn?

From this main question the following sub-questions can emerge:

1. To what extent is content and language integrated learning effective in developing primary official language school pupils' EFL overall components of the speaking skill?

2. To what extent is content and language integrated learning effective in developing primary official language school pupils' EFL each component of the speaking skill namely: (grammar, vocabulary, pronunciation, fluency and comprehension)?

3. To what extent is content and language integrated learning effective in developing primary official language school pupils' motivation to learn?

4. What is the relation between the pupils' scores on the speaking skills test and theirs on the motivation scale?

\subsection{Hypotheses of the study}

To achieve the aim of the present study, the following hypotheses were formulated:

1. There is a statistically significant difference at (0.01) between the experimental and the control groups' mean scores in the overall speaking skills post test in favor of the experimental group.

2. There is a statistically significant difference at $(0.01)$ between the experimental and the control groups' scores in each component of the speaking skill post test in favor of the experimental group.

3. There is a statistically significant difference at $(0.01)$ between the experimental and the control groups' mean scores in the post administration of motivation scale in favor of the experimental group.

4. There is a statistically significant correlation at (0.01) between the experimental group pupils' scores on speaking skills test and theirs on motivation scale.

\subsection{Delimitations of the study}

The present study is delimited to:

- Some speaking skills: pronunciation, grammar, vocabulary, fluency and comprehension. 
- Sixty pupils enrolled in Defino primary official language school at Fayoum governorate.

- $\quad$ First semester of the academic year 2020-2021.

\subsection{Aim of the study}

The present study aimed at developing primary official language school pupils' EFL speaking skills and their motivation to learn through the use of content and language integrated learning.

\subsection{Significance of the study}

The present study might help:

- primary official language school pupils to speak and participate more actively in classroom activities

- direct teachers' attention to the use of content and language integrated learning in teaching.

- highlight new avenues to researchers in EFL teaching and learning.

\subsection{Terminology}

\section{Content and Language Integrated Learning (CLIL)}

The term content and language integrated learning is used in the present study to refer to an educational approach to teaching fifth year primary official language school pupils' Science content using English language as a medium of instruction .

\section{EFL Speaking Skills}

The researcher used the term EFL speaking skills in the present study to refer to fifth primary pupils' ability to express themselves orally, exchange ideas and communicate in EFL.

\section{Motivation}

The term motivation is used in the present study to refer to the desire or willingness of fifth primary pupils to study scientific content using English language, initiate speech and participate in classroom activities more effectively.

\section{Primary official language school pupils}

They are fifth year Defino primary official language school pupils at Fayoum governorate ( $\mathrm{N}=60$ ) who study content subjects ( e.g. Science and Mathematics ) in English language. In this study Science not Mathematics is concerned. 


\section{Review of literature}

\subsection{EFL Speaking skills}

Among the four basic skills of the English language, speaking is a major skill in communication. The process of communication is considered the ultimate goal of language learning (Rao, 2019). There are many definitions of speaking that have proposed by researchers. For example, Laksana (2016) defined speaking as a skill to use a language appropriately to express one's ideas, opinions or feelings to give or get information to/ from others.

Also, Luoma (2004) defined speaking as an interactive process of constructing meaning involves producing, receiving and processing information. The researcher used the term operationally to refer to fifth primary pupils' ability to express their ideas orally and communicate in EFL.

\section{The importance of EFL speaking skills}

The importance of speaking skills is undeniable for EFL learners. It promotes communicative efficiency as a majority of communication is done through speech. Teachers usually encourage and help students to use language fluently and correctly as much as possible. Learners also give the speaking skill priority in their learning because it is the active use of language to express meaning (Imane, 2016).

Regardless of its importance, teaching speaking skills is overlooked or undervalued. Teachers devote classroom time to written language, grammatical correction and reading skills as they teach to the test (Pakula, 2019). However, the modern world demands developing learners' communication skills. So, English teachers have to provide learners with the needed skills to improve their abilities to speak and perform well in real - life situations (Rao, 2019).

The ability to use the language as a means of communication often judges one' successfulness in speaking class in language learning. This success is detected when a language learner can use the language to express his own ideas, feelings, and thoughts in the form of monologue or when s/he is able to make a conversation with others (Manurung, 2015). As a result, many learners often evaluate their success in language learning as well as the effectiveness of their English course on the basis of how much they fell they have improved in their spoken language proficiency (Sayin, 2015).

\section{Components of EFL speaking skill}

Kurum (2016) stated three components including:

- Mechanics (pronunciation, grammar, and vocabulary): using the right words in the right order with the correct pronunciation. 
- $\quad$ Functions (transaction and interaction): knowing when clarity of message is essential (transaction/ information exchange) and when precise understanding is not required (interaction/ relationship building).

- $\quad$ Pragmatics, social and cultural rules and norms ( turn - taking, rate of speech, length of pauses between speakers): taking into account who is speaking to whom, in what circumstances, about what, and for what reason.

According to many teaching theorists, speaking skill can be developed through communicative activities which include information gap, jigsaw puzzles, games, problem solving, role-playing and discussion. Such activities help create interaction in the language classroom. Additionally, they can motivate the learners and establish friendly relationships between the teacher and the students as well as among the students encouraging a positive and supportive language learning environment ( Oradee, 2012).

According to Hui ( 2011), there are five components of speaking skills: grammar, vocabulary, pronunciation, fluency and comprehension. First, grammar refers to the ability to manipulate structures, produce appropriate grammatical forms and to use them effectively in communication. Second, vocabulary can be defined as the appropriate diction which is used in communication.

The third component is pronunciation that refers to the way the student produce the utterances and sentences clearly. Fourth, fluency can be defined as the ability to speak fluently and accurately. Fluency refers to the process of expressing oral language freely, smoothly and expressively. The last component is comprehension. For oral communication to occur, understanding speech, responding to oral stimulus and initiating speech are required.

\section{Studies related to EFL speaking skills}

There are several studies that dealt with developing speaking skills. To the researcher's knowledge, the most up to date studies are the following:

Safitri, Rafli and Dewanti (2020) investigated the effect of task based learning on developing students' speaking skills. Participants were fifteen student enrolled in English Department in their third semester in South Tanggerang, Indonesia. The data were taken from the results of the pre-test to post-test, interview, and observation. The findings revealed that the use of task-based learning helps the students improve their speaking skills of three indicators assessed: accuracy, vocabulary, and comprehension.

Juniardi, Herlina, Lubis and Pahamzah (2020) compared the effectiveness of computerand mobile-assisted learning on the EFL students' speaking skills development. Participants were thirty students enrolled in one state junior high school in Banten Province. This research used Classroom Action Research (CAR) as the research method. The data analysis used quantitative data that was obtained from the test, observation sheet and questionnaire. Results 
confirmed that the use of Macromedia Flash and Smartphone could generate effective teaching and learning processes to improve the students' speaking skills.

Mohamed (2019) examined the effectiveness of dogme in developing the student teachers' speaking skills as well as their speaking self- efficacy The research adopted the one group research design. Participants consisted of $(\mathrm{N}=44)$ freshmen students English majors at the faculty of education in Beni Suef. The instruments and materials of the study represent in a pre-post speaking test, and a speaking self-efficacy scale, a checklist of speaking skills, a speaking rubric and ELT dogme. The research results revealed that dogme ELT has a positive impact on enhancing students' speaking skills as well as their speaking self-efficacy.

\subsection{Motivation}

Motivation is a theoretical construct used to explain behavior. It represents the reasons for people's actions, desires, and needs. Chilingaryan and Gorbatenko (2015) defined motivation as a desire to achieve a goal, combined with the energy to work towards that goal. Turabix and Baskan (2015) stated that motivation process shows that each individual has some needs they strive to satisfy. These needs drive the individual to behave in a certain direction; the individual needs to be aroused for triggering off a driving force. This force represents the physical and mental incentives. An aroused individual acts in order to satisfy his/her needs and finally reaches the satisfaction point.

Motivation can be conceived of as a cycle in which thoughts influence behaviors, behaviors drive performance. Performance impacts thoughts, and the cycle begins again. Each stage of the cycle consists of many dimensions including attitudes, beliefs, intentions, effort, and withdrawal which can all affect the motivation that an individual experiences (Tohidi \& Jabbari, 2012).

Chilingaryan and Gorbatenko (2015) stated four sources of motivational needs: behavioral, biological, cognitive and conative sources. First, behavioral sources of motivational needs are to obtain desired rewards and avoid unpleasant consequences, as well as to initiate positive models. Second, biological sources activate senses, increasing, decreasing stimulation, while affective sources increase, or decrease affective dissonance, making us fell good and decreasing the feeling of bad mood. Third, cognitive sources, as the name suggests, maintain attention to something interesting, develop meaning or understanding, eliminate threat or risk. Finally, conative sources help an individual to obtain personal dream, take control of one's life and contribute to understanding the purpose of one's life.

\section{Key Factors of Motivation}

There are three key factors of motivation: positive attitude towards L2 community, the enjoyment of learning, and external pressures. Firstly, positive attitude towards L2 community, motivation to learn a FL depends on the attitudes towards such community. Learners must have a positive attitude towards FL community and the desire to become a 
member of that community. Secondly, the enjoyment of learning, there should be some sort of enjoyment while learning to be motivated to continue studying the FL. Intrinsically motivated learners are more likely to continue their studies and participate in learning activities for the pleasure of learning the FL and the culture of that community. Finally, external pressures, there are external pressures that motivate learners to learn the FL such as pleasing parents, receiving a reward, or fulfilling some pragmatic aims (Alizadeh, 2016).

\section{Types of motivation}

There are four types of motivation : instrumental, integrative, intrinsic and extrinsic motivation. Saheb ( 2014) differentiated between

instrumental and integrative motivation. The instrumental motivation refers to acquiring a language as a means for obtaining instrumental objectives such as furthering a career or reading technical materials, or even translation. It refers to the potential utilitarian gains of FL proficiency while the integrative motivation refers to positive attitudes and feelings towards the target language group. It describes learners who want to integrate themselves into the culture of the second language group and become involved in social interchange in that group.

Tohidi and Jabbari (2012) differentiated between intrinsic and extrinsic motivation. Intrinsic motivation refers to motivation that is driven by an interest or enjoyment in the task itself, and exists within the individual rather than relying on any external pressure. It is usually associated with high educational achievement. Intrinsically motivated learners usually attribute their educational results to factors under their own control. They can work hard to reach desired goals and are interested in mastering a topic, rather than just rote- learning to achieve good grades.

On the other hand, extrinsic motivation comes from outside of the individual. Common extrinsic motivations are rewards like money and grades, coercion and threat of punishment. Social psychological research has indicated that extrinsic rewards can lead to over justification and a subsequent reduction in intrinsic motivation.

\section{Motivation and language learning}

Motivation is a thing that can increase students' determination and interest in language learning. It provides learners with an aim and direction to follow. Therefore, it has a key role in language learning (Alizadeh, 2016). Moreover, language teachers frequently use the term motivation to describe successful or unsuccessful learners. Undoubtedly, learner's enthusiasm, commitment and persistence are key determinants of his/ her success or failure. Without sufficient motivation, it is very difficult for learners to gain effective learning, even the brightest learner are unlikely to persist long enough to attain any useful language (Hadfield \& Dornyei, 2014).

All learners, teachers, material developers, and researchers agree that motivation is an important part of mastering a foreign language. So, it can be stated that teachers should be 
aware of significance of motivation in learners' language learning and through some changes they can help learners increase their motivation (Alizadeh, 2016).

\section{Motivation and CLIL}

Motivation, which is the driving force in any classroom situation, is an important affective variable to consider in a CLIL classroom. In the CLIL classroom, the motivated student expends effort to learn both content and language. Also, s/he expresses desire to succeed and will strive to achieve success. Such student enjoys the task of learning content through a foreign language and considers it to be fun ( Papaja \& Rojczyk, 2013).

CLIL, with its integration of language and non-language content, can boost motivation by providing a legitimate and authentic context for language use. In CLIL, the language becomes the means rather than the end in itself and this leads to a significant reduction in the amount of anxiety expressed by learners (Lasagabaster \& Sierra , 2009). Language is learnt more successfully when the learner has the opportunity to gain subject knowledge at the same time ( Darn , 2015)

\section{Studies related to CLIL and motivation}

To the researcher's Knowledge, there are two studies that dealt with CLIL and motivation. These include Mede and Çinar (2018) as well as Alcántara (2013). Mede and Çinar (2018) examined the effects of integrating Content and Language Integrated Learning (CLIL) on the motivation of students learning English in a preparatory school at a private university in Istanbul, Turkey. Participants of the study consisted of 19 intermediate level students. To meet the study aim, pre/post motivation questionnaires and reflective journals were used. Results showed that students and their instructor perceived CLIL as an engaging and functional instructional tool while teaching and learning English. Also, CLIL helped students to become more motivated and responsible for their own learning process.

Alcántara (2013) compared motivation of students who belong to CLIL schools and nonCLIL schools. Participants of the study were 20 students of the CLIL school Espíritu Santo (Baena), acting as the experimental group, and 19 students of the non-CLIL school José Salazar (El Ejido), acting as the control group .Two questionnaires were used to assess motivation and CLIL. Results showed that CLIL students appear to be more motivated in English as a foreign language and interested in CLIL than non-CLIL students.

\subsection{Content and Language Integrated Learning (CLIL)}

Content and Language Integrate Learning (CLIL) is an umbrella term created in Europe in 1994 by David Marsh and Anne Maljers to describe an educational approach for learning content through an additional language (foreign or second) using this language as a medium of instruction (Sulistova, 2013).

This approach is based on the success of the Canadian immersion model that began in the mid-1960s, in which curriculum content is taught through the medium of the students' non- 
native language (Cross \& Gearon, 2013). The essence of CLIL is that content subjects are taught and learnt in a language which is not the mother tongue of the learners (Darn, 2015). The basic idea behind the integration of content and language is that languages are not learned first and then used but that they are learned by being used (Diab, 2018).

Many definitions of CLIL are proposed by many researchers such as Coyle, Hood and Marsh (2010) who defined it as a dual - focused educational approach in which an additional language is used for learning and teaching of both content and language. There is a focus not only on content and not only on language. Each is interwoven- even if the emphasis is greater on one than the other at a given time.

Another definition is provided by Escobar (2019) who defined it as a plurilingual approach to learning and teaching in formal contexts that creates a space which naturally leads to the implementation of Halliday's triadic perspective on (language) learning by placing the language learning continuum at its very heart.

Sulistova (2013) states that there are two kinds of CLIL: the so - called hard CLIL and soft CLIL. Hard CLIL means that the subject or subject curriculum is taught in a foreign language. However, the main lesson objective is the content objective, not the language, while in the socalled soft CLIL a higher emphasis is put on learning the language.

\section{Importance of CLIL}

CLIL, that supports the development of language and cont concurrently, helps to develop language skills in the target language as well as specific knowledge beyond concepts of the subject promoting students' ability to a acquire proficiency in several languages and experiences of several cultures (Diab, 2018).

CLIL has numerous linguistic, educational and cultural advantages. Linguistically, It leads to greater linguistic proficiency because it allows learners more contact with the target language. CLIL not only improves overall target language proficiency, but also raises awareness of both mother tongue and target language while encouraging learners to develop plurilingual interests and attitudes. Educationally, CLIL adds diversity and flexibility to the existing learning strategies, methods and forms of classroom practice. It is suitable for learners of all abilities. Culturally, it leads to greater intercultural awareness, competence and sensitivity. It helps to build intercultural knowledge and understanding by developing intercultural communication skills while learning about other countries/ regions and / or minority groups. It helps communication across cultures. ( Cross \& Gearon, 2013 ; Harrop, 2012)

Sulistova (2013) pointed out that there are positive aspects of CLIL. It enhances learners' critical thinking, is based on real life situations, is based on team work or projects, breaks fear of traveling outside the home country. Moreover, it enlarges students' motivation in learning the target language, employs English as lingua France, provides up - to - date 
materials and resources and develops a wide range of multidisciplinary and communicative skills.

\section{Features of CLIL}

Gil (2010) stated that there are common features of CLIL: naturalistic and implicit learning, cooperative learning, scaffolding, authenticity and flexibility. CLIL creates conditions for naturalistic language learning by focusing on meaning and communication and providing great amounts of input. Also, most CLIL - based courses expect pupils to support each other through cooperative learning techniques in which learners work in groups. Moreover, scaffolding is an essential component of CLIL, since the main aim of CLIL is to guide language processing and support language production. CLIL should scaffold the relationship between the language and non - language contents of the curriculum at all levels of language teaching. Furthermore, CLIL classes often involve an intensive use of materials designed for educational purposes to enrich the context offered by real materials, which are chosen to be the core of the thematic unit. Finally, CLIL is an educational innovation that suits the times, needs and aspirations of all learners, for this reason, many authors describe CLIL as an umbrella approach.

\section{CLIL 4Cs pedagogic framework}

- $\quad$ The framework underpinning CLIL is known as 4Cs Framework. This framework has been the most common theoretical guidance for planning CLIL lessons and constructing materials because of its integrative nature. It is based on the following principles (Harrop , 2012 ; Diab, 2018 ; Coyle et al., 2010 ):

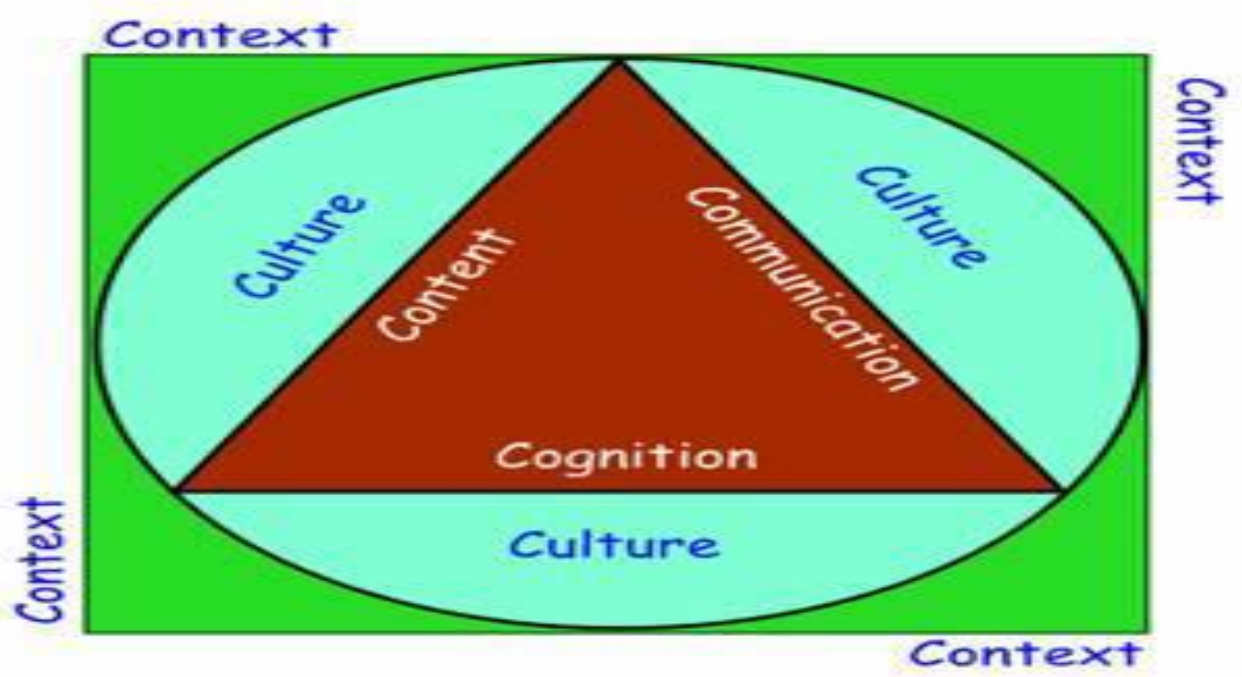

Figure1: The CLIL 4Cs Framework, source: Coyle et al. $(2010,41)$

- $\quad$ Content: the subject matter, theme, and topic forming the basis for the course, defined by domain or discipline according to knowledge, concepts, and skills. 
- Communication: the language to create and communicate meaning about the knowledge, concepts, and skills being learned.This language needs to be transparent and accessible interaction in the learning context is fundamental to learning.

- Cognition: the ways that we think and make sense of knowledge, experience, and the world e.g. remembering, understanding, evaluating, critiquing, reflecting, creating).

- Culture: the ways that we interact and engage with knowledge, experience, and the world around us; socially, pedagogically and according to the discipline

\section{CLIL and classroom}

A CLIL lesson follows a four-stage framework: 1) processing the text, 2) identification and organization of knowledge, 3) language identification and 4) tasks for students.

\section{1- Processing the Text.}

The best texts are those accompanied by illustrations so that learners can visualize what they are reading. When working in a foreign language classroom, learners need structural markers in texts to help them find their way through the content. These markers may be linguistic (headings, sub-headings, tables).

\section{2- Identification and Organization of Knowledge.}

Texts are often represented diagrammatically. These structures are known as diagrams of thinking, and are used to help learners categorize the ideas and information in a text. Diagram types include tree diagrams for classification, groups, hierarchies, flow diagrams and timelines for sequenced thinking. The structure of the text helps to facilitate learning and the creation of activities which focus on both language development and core content knowledge.

\section{3- Language Identification.}

Learners are expected to be able to reproduce the core of the text using their own words. So, the teacher should highlight useful language in the text and categorize it according to function. Learners may need the language of comparison and contrast, location or describing a process. Also, they may need certain discourse markers, adverb phrases or prepositional phrases. Moreover, collocations, semi-fixed expressions and set phrases should be given attention as well as subject specific and academic vocabulary.

\section{4- Tasks for Students.}

A variety of tasks should be provided, taking into account the learning purpose and learner styles and preferences (Diab, 2018 ; Darn,2015). 


\section{Teachers of CLIL}

Teachers of CLIL should have basic skills and competences. They should have a degree in a particular subject and at the same time a degree in a foreign language; or a willingness to develop or deepen their knowledge from the other subject. They focus on the content of the disciplinary message, introduce linguistic support in the task design and build interactional scaffolding for learners to participate in academic discourse (Escobar, 2019).

In addition, a language teacher should cooperate with a subject teacher to be acquainted with a certain non- language subject, the role of teamwork during lessons, CLIL methodology, the way of assessment, how to provide feedback, dealing with multicultural groups, didactics in a multinational group, etc. (Bonces, 2012).Cooperation and teamwork are vital components to the successful implementation of CLIL approach at any given educational institution (McDougald, 2015).

\section{Models of CLIL}

There are a number of models for integrating content areas in language e.g Charalampidi et.al's (2017) and Sabra's (2017) model that depended on the CLIL 4Cs framework: content, cognition, communication and culture. The other model is Diab's (2018) one that depended on some phases which are processing the text, identification and organization of knowledge, language identification and tasks for students. The researcher, for the nature of the study, adopted Diab's model for being appropriate for the present study.

\section{Studies related to CLIL and speaking}

Sabra (2017) investigated the effect of a CLIL-based program on developing some History section students' language skills. Participants of the study were 16 second year of History section students studying historical texts in an English language course at Hurghada Faculty of Education. He used a quasi pre-post experimental one group design. A pre/post speaking test, a pre/post writing test and a pre/post test in vocabulary were used to collect data. Results of the study confirmed that the CLIL-based program had an effective way on developing students' level of fluency in speaking and accuracy in writing skills

Dellio and Zafiri (2016) examined the potential of CLIL in the development of speaking skills of students in the sixth grade of primary school. Participants of the study were thirty students who belong to two different state primary schools of the same area. They were divided into two groups of fifteen students each. The control group was taught using the regular method while the experimental group was taught following CLIL. Speaking tests, observation sheets and a questionnaire were used to collect data. Results showed the effectiveness of CLIL in developing experimental group students' speaking skills. Also, they had favorable attitudes towards CLIL.

Czura and Kołodyńska (2015) investigated the effect of CLIL-type instruction in a Mathematics classroom on developing Polish pupils' oral communicative competence. 
Participants of the study were 36 pupils from the sixth grade of primary school. They were divided into two groups: experimental and control each comprising 18 pupils. Pre/ post tests of oral communicative competence and interviews were used to collect data. The quasiexperimental design was used. Results revealed the positive effect of CLIL on developing the experimental group pupils' speaking skills, especially in terms of vocabulary, fluency and pronunciation.

\section{Method}

\section{A. Participants}

Participants of the present study consisted of sixty pupils divided into two groups; experimental and control 30 pupils each. They were randomly selected from fifth year pupils enrolled in Defino primary official language school, Fayoum governorate, Egypt.

\section{B. Design}

The researcher used the quasi experimental with experimental/control pre/post test design.

\section{Instruments and Materials}

To fulfill the aim of the present study, the following instruments and materials were designed including an EFL speaking test, an EFL speaking rubric, a motivation scale and a teacher's guide.

\subsection{The EFL Speaking Skills Pre-Post Test}

After making the speaking skills checklist (see appendix 1) and validating it by a panel of jury members, the EFL speaking test was prepared.

\subsubsection{The aim of the EFL speaking skills pre-post test}

The aim of this test was to measure speaking skills among fifth year Defino primary official language school pupils for both the experimental and control groups. It was used as a pre-post test. As a pre test, it was used to determine the participants' level in EFL speaking skills before the treatment. As a post test, it was used to investigate the effectiveness of CLIL in developing participants' speaking skill.

\subsubsection{Description of the test}

The speaking skill pre-post test consisted of three questions described as follows:

1- The first question required pupils to retell what they know about one of these topics:

a) - magnetic materials and non-magnetic ones or b)- transparent materials and semitransparent ones. 
2- The second question was a dialogue between Ibrahim and Ali who are talking about fruit salad as a mixture.

3- The third question required pupils to describe some pictures orally (see appendix 2).

\subsubsection{Validity of the test}

The EFL speaking test was submitted to a panel of jury members $(\mathrm{N}=5)$ (see appendix 3 ). They were asked to determine the validity of the test in terms of clarity and suitability for the pupils' level . They indicated that the test instructions were clear and suitable for the pupils' levels ( Face Validity). To ensure the content validity of the test, it was developed in the light of a systematic and accurate review of literature and previous studies. This accurate and systematic review determined the general form of the test, and how it should be graded and/or scored. Therefore, the content of the test was representative of the skills that were intended to be measured. Thus, the test was valid.

\subsubsection{Inter-rater reliability of the test}

To ensure test reliability, inter-rater reliability was used in which three different raters (the researcher and two science teachers) assessed pupils ' answers. The reliability of the rubric was found to be (0.74) which is an acceptable level of reliability.

\subsubsection{Scoring the test}

Three raters rated pupils' answers giving a score out of fifteen to each question. The total mark of the test is 45 .

\subsubsection{Piloting the test}

Piloting the test aimed at determining clarity, reliability and estimating the time needed for taking the test. The test was piloted on (15) pupils other than those of the main treatment. The speaking test time was $r 5$ minutes. This took place by computing the time taken by each pupil divided by the number of the pupils (15).

\section{2 The speaking rubric}

\subsubsection{The aim of the speaking rubric}

The rubric was prepared to help in scoring the test in an objective manner. The researcher and two science teachers depended on it to give a score out of 5 for each skill.

\subsubsection{Description of the rubric}

The rubric contained 5 speaking skills: pronunciation, vocabulary, grammar, fluency and comprehension. Also, it included 5 levels of performance, ranging from 5 to 1 . Each level included a set of indicators for assessing the performance of each speaking skill. 
Thus, each level indicator gave a quantitative grade score for scoring students' spoken performance (see appendix 4).

\subsubsection{Validity of the rubric}

To estimate validity, the rubric was submitted to a panel of jury members. They confirmed that the rubric is valid.

\subsection{4-Reliability of the rubric}

The split -half method was used to determine the reliability of the rubric. The correlation coefficient was $(0.77)$ reflecting that the rubric is highly reliable.

\subsection{The motivation scale}

\subsubsection{The aim of the motivation scale}

The scale aimed at collecting data and measuring pupils' motivation before and after the treatment.

\subsubsection{Description of the scale}

The motivation scale consists of 30 items where the participants were asked to underline the item(s) that indicate(s) how often they do it. The scale consists of three dimensions: motivation to learn comprising 7 items, motivation to learn English containing 9 items and motivation to speak English including 14 items. The participants were asked to rate the frequency of each category on a 3-point Likert-scale, ranging from never, sometimes, to always (0-2) points, respectively (see appendix 5).

\subsubsection{Validity of the scale}

To estimate validity, the scale was submitted to a panel of jury members. They indicated that the scale is valid after making the required modifications. Some of these modifications were "I allocate a certain amount every day to study English language" instead of "I study English language every day" and "I feel freer to express myself in English than I do in first language" instead of "I feel freer to express myself in English".

\subsection{4-Reliability of the scale}

The split -half method was used to determine the reliability of the scale. The correlation coefficient was $(0.72)$ reflecting that the scale is highly reliable.

\subsection{The teacher's guide}

\subsection{Aim and objectives of the teacher's guide}

The guide aimed to help primary official language school teachers develop their pupils' speaking skills and motivation to learn through using CLIL (see appendix 6). 


\section{Objectives}

By the end of the sessions, pupils are expected to be able to:

-develop scientific vocabulary terms and use it in speech.

-develop their pronunciation of scientific terms.

-produce oral sentences correctly in terms of grammar and pronunciation.

- differentiate between scientific terms appropriately.

- use grammatical rules and structures correctly.

-use word and sentence stress appropriately.

-produce sentences and exchange information fluently.

-use certain language functions appropriately.

- respond to a certain situation appropriately .

-ask their teacher or classmates for information orally.

\subsection{2-Content}

The researcher adapted some Science lessons from the first semester textbook of primary five of the academic year 2020/2021 to be taught via CLIL. The lessons were shown in the following table.

Table (1) Sessions of the teacher's guide

\begin{tabular}{|l|l|}
\hline Session & \multicolumn{1}{|c|}{ Title } \\
\hline 1 & An Introductory Session \\
\hline 2 & Light \\
\hline 3 & Magnetism \\
\hline 4 & Mixtures \\
\hline 5 & Solutions \\
\hline 6 & Food relationships among living organisms \\
\hline 7 & Environmental balance \\
\hline
\end{tabular}

These sessions were preceded by a session devoted to administrating the pre-test and followed by another session devoted to post-testing. The total sessions were 9 .

\subsubsection{Activities and techniques}

Various individual, pair and group work activities were used. Each session contained individual activities and other activities that require pairs of pupils to confer with each other. 
Some other activities were group-based where groups of pupils were asked to confer and become involved in discussion and conversation. Individual and group pupils were encouraged to self - question and generate questions of their own.

\subsubsection{Evaluation}

The researcher used the two types of evaluation; namely formative and summative evaluation. The formative evaluation was represented in the questions and exercises pupils were asked to carry out during the sessions whereas the summative evaluation was represented in the post test administered to the pupils at the end of the sessions.

\subsubsection{Experimental procedures}

\section{- $\quad$ Pre-testing}

Pre-testing of the speaking skills test took place on $1^{\text {st }}$ November 2020 . This was done to recognize the pupils' entry level before the treatment.

\section{- $\quad$ Treatment}

Teaching sessions were based on CLIL .There were seven sessions devoted to enhancing the experimental group's speaking skills and motivation to learn. They took place on $5^{\text {th }}$ November 2020 and ended on $12^{\text {th }}$ December 2020 .In the first session, the researcher introduced CLIL to the pupils and explained to them what they are going to do. At the beginning of the treatment, the researcher noticed that learners encountered some difficulties in understanding, pronouncing and recognizing some scientific terms and topics.

Throughout the treatment, learners were encouraged to speak up and discuss scientific concepts using various activities suitable for their preferences and learning styles. Also, the researcher helped pupils to be more motivated to speak without the fear of making mistakes through delaying the correction of some grammatical and pronunciation mistakes and tolerating minor ones that do not affect understanding and communication. At the end of the treatment, learners acquired confidence in the target learning developing both the scientific content and speaking skills. Also, they have become more motivated to speak and exchange information.

\section{- $\quad$ Post-testing}

At the end of the treatment, the researcher evaluated pupils' speaking skills through administering the speaking post-test with the aim of investigating the effectiveness of CLIL in developing official primary school pupils' speaking skills and motivation to learn.

Data were treated statistically and the results and discussion will be dealt with in the following section. 


\section{Findings of the study}

The findings of the present study are presented in the light of the hypotheses using the Statistical Package for Social Sciences (SPSS) version 26.

\subsection{The first hypothesis}

The first hypothesis states that "There is a statistically significant difference at $(0.01)$ between the experimental and the control groups' mean scores in the overall speaking skills post test in favor of the experimental group".

Table (2)" t" value of the experimental and the control groups in the post administrations of overall EFL speaking skills.

\begin{tabular}{|l|c|l|c|c|c|l|}
\hline Groups & N & Mean & S.D & T-Value & D.F & Sig. \\
\cline { 1 - 4 } Experimental & 30 & 87.90 & 1.55 & 48.88 & \multirow{2}{*}{58} & \multirow{2}{*}{0.01} \\
\hline Control & $3 \cdot$ & 54.15 & 4.07 & & & \\
\hline
\end{tabular}

Table (2) shows that the experimental group pupils' posttest scores are significantly higher than the control group ones in overall EFL speaking skills. They attained a higher mean score in the posttest (87.90 ) than that of the control group (54.15). T - value is $(4 \wedge . \wedge 8$ ) and this difference is significant at (.01) level .Thus, the first hypothesis of the study was supported.

\subsection{The second hypothesis}

The second hypothesis states that "There is a statistically significant difference at $(0.01)$ between the experimental and the control groups' mean scores in each component of the speaking skill post test in favor of the experimental group ".

Table (3)" t" value of the experimental and the control groups in the post administrations of each component of the speaking skill.

\begin{tabular}{|c|c|c|c|c|c|c|c|}
\hline $\begin{array}{c}\text { Components of } \\
\text { Speaking } \\
\text { Skills }\end{array}$ & Groups & $\mathrm{N}$ & $\mathrm{M}$ & S.D & T-Value & D.F & Sig. \\
\hline \multirow[t]{2}{*}{ vocabulary } & Experimental & 30 & 19.50 & 0.55 & \multirow{2}{*}{54.79} & \multirow{2}{*}{58} & \multirow{2}{*}{0.01} \\
\hline & Control & 30 & 13.22 & 0.45 & & & \\
\hline \multirow[t]{2}{*}{ grammar } & Experimental & 30 & 19.45 & 0.55 & \multirow[t]{2}{*}{51.94} & \multirow[t]{2}{*}{58} & \multirow[t]{2}{*}{0.01} \\
\hline & Control & 30 & 13.36 & 0.47 & & & \\
\hline \multirow[t]{2}{*}{ pronunciation } & Experimental & 30 & 4.45 & 0.51 & \multirow{2}{*}{12.36} & \multirow[t]{2}{*}{58} & \multirow[t]{2}{*}{0.01} \\
\hline & Control & 30 & 3.25 & 0.44 & & & \\
\hline \multirow[t]{2}{*}{ fluency } & Experimental & 30 & 4.05 & 0.48 & \multirow[t]{2}{*}{17.03} & \multirow[t]{2}{*}{58} & \multirow[t]{2}{*}{0.01} \\
\hline & Control & 30 & 2.50 & 0.38 & & & \\
\hline \multirow[t]{2}{*}{ comprehension } & Experimental & 30 & 4.80 & 0.41 & \multirow{2}{*}{21.72} & \multirow[t]{2}{*}{58} & \multirow[t]{2}{*}{0.01} \\
\hline & Control & 30 & 2.60 & 0.50 & & & \\
\hline
\end{tabular}


To verify the second hypothesis, t-test was calculated. Results confirmed that the t- value of vocabulary component (54.79) that is significant at 0.01 level in favor the experimental group . Also, the t- value of grammar component is (51.94) that is significant at 0.01 level in favor of the experimental group. In addition, the t- value of pronunciation component is (12.36) that is significant at 0.01 level in favor of the experimental group. Moreover, the t- value of fluency component is (17.03) that is significant at 0.01 level in favor of the experimental group. Finally, the t- value of comprehension component is (21.72) that is significant at 0.01 level in favor of the experimental group. Thus, the second hypothesis of the study was supported

\subsection{The third hypothesis}

The third hypothesis states that "There is a statistically significant difference at $(0.01)$ between the experimental and the control groups' mean scores in the post administrations of motivation scale in favor of the experimental group".

Table (4)" t" value of the experimental and the control groups in the post administrations of motivation scale.

\begin{tabular}{|l|c|c|c|c|c|c|}
\hline Groups & $\mathrm{N}$ & Mean & S.D & T-Value & D.F & Sig. \\
\hline Experimental & 30 & 18.75 & 2.94 & \multirow{2}{*}{8.155} & \multirow{2}{*}{58} & \multirow{2}{*}{0.01} \\
\hline Control & 30 & 14.60 & 2.85 & & & \\
\hline
\end{tabular}

Table (4) shows that the experimental group pupils' posttest scores are significantly higher than the control group ones in motivation scale. They attained a higher mean score in the posttest (18.75) than that of the control group (14.60). $\mathrm{T}$ - value is ( 8.155 ) and this difference is significant at (.01) level .Thus, the third hypothesis of the study was supported.

\subsection{The Fourth hypothesis}

The fourth hypothesis states that "There is a statistically significant correlation at $(0.01)$ between the experimental group pupils' scores on speaking skills test and theirs on motivation scale".

Table (5) Pearson Correlation between the experimental group pupils' scores on speaking skills test and theirs on motivation scale.

Correlations

\begin{tabular}{|l|l|c|c|}
\hline \multicolumn{2}{|c|}{} & $\begin{array}{c}\text { Speaking } \\
\text { test }\end{array}$ & $\begin{array}{c}\text { Motivation } \\
\text { scale }\end{array}$ \\
\hline \multirow{3}{*}{ Speaking test } & Pearson correlation & 1 & .882 \\
\cline { 2 - 4 } & Sig. (2-tailed) & & .001 \\
\cline { 2 - 4 } & $\mathrm{N}$ & 30 & 30 \\
\hline \multirow{3}{*}{ Motivation scale } & Pearson correlation & .882 & 1 \\
\cline { 2 - 4 } & Sig. (2-tailed) & .001 & \\
\cline { 2 - 4 } & $\mathrm{N}$ & 30 & 30 \\
\hline
\end{tabular}


Table (5) shows that there is a significant correlation between the experimental group pupils' scores on speaking skills test and theirs on motivation scale (.882) at (0.01). Thus, the fourth hypothesis of the study was supported.

\section{Discussion of the Results}

The aim of the present study is to develop speaking skills and motivation to learn among fifth year official primary school pupils using CLIL. The results of the study revealed that CLIL proved to be effective in developing the experimental group pupils' overall speaking skills and their motivation to learn. These results are in line with the studies of Dellio and Zafiri (2016) as well as Czura and Kołodyńska (2015) who confirmed that CLIL has a positive effect on developing learners' speaking skills. Also, the study results agree with the studies of Mede and Çinar (2018) and Alcántara (2013) who assured that CLIL helped students to become more motivated and responsible for their own learning.

The use of various diagrams or visual language, as what CLIL requires, helped to attract pupils' attention and facilitate their learning of scientific terms. Also, the use of various tasks or activities suitable for pupils' learning styles and preferences such as questioning, discussion, role play and information gap exercises, again as what CLIL requires, encouraged pupils to be more motivated to speak using English language as a means of communication. Moreover, the researcher's delayed correction of some of the pupils' mistakes tolerating some others encouraged and motivated them to initiate speech overcoming their shyness and fear of making mistakes and being criticized by their classmates.

Furthermore, the present study confirmed that there is a positive correlation between the experimental group pupils' speaking skills and their motivation to learn. Pupils, who got high scores in the speaking skills test, were more motivated to speak and learn using English language. .

CLIL helped pupils to be more enthusiastic, confident and motivated. It encouraged them to speak up and enabled them to exchange information and thoughts developing both the scientific content and speaking skills. Some of pupils' comments were

- $\quad$ I like the way I learn Science now.

- I I Iike to speak English with my teacher and classmates..

- $\quad$ I do not feel shy to speak English in class.

- $\quad$ The teacher gives me two presents and I want to get more.

In addition, CLIL helped reduce teacher talking time because it increased pupils' participation in different speaking activities. Finally, it provided a supportive learning environment for both content and language development. Being enthusiastic, self-assured and motivated, a learner can learn effectively. 


\section{Conclusion}

The results of the study showed that fifth year official primary school pupils' speaking skills and motivation to learn were improved after the use of CLIL. Therefore, the significant differences found in favour of the experimental group in the post administration of the speaking skills test and motivation scale can be ascribed to the implementation of the treatment based on the use of CLIL. The experimental group's improvement in the speaking skill was not only in the overall speaking skills, but also in each speaking skill/component of the speaking skills. They become more motivated to speak and participate in classroom activities.

\section{Recommendations of the study}

In the light of the previous results, the following recommendations could be presented:

1-EFL curricula designers have to select the content that suits the learners and that is relevant to what they study in other subject matters.

2-The teachers need to know how to integrate linguistic features into the teaching of content subject.

3-CLIL should be emphasized in different educational stages.

4- There should be movement or shift from teacher/fronted classroom to student-centered classroom.

\section{Suggestions for further research}

Based on the findings of the present study the following suggestions are presented.

1-Investigating the effect of CLIL on developing other language skills such as reading and writing.

2- Using CLIL for teaching reading to technical and vocational secondary school students.

3- Using CLIL to develop college learners' higher order thinking skills.

4-Using CLIL to develop college students' oral communication skills

\section{References}

Alcántara, E. (2013). A Comparative Research of Motivation of Students of a CLIL School and a Non-CLIL School. Unpublished M.A. Thesis .Retrieved from http://repositorio.ual.es/bitstream/handle/10835/2607/Trabajo.pdf?sequence $=6$

Alizadeh, M. (2016). The impact of motivation on English language learning. International Journal of Research in English Education, 1 (1), 11-15. 
Charalampidi, M., Hammond, M., Hadjipavlou, N., \& Lophitis, N. (2017). A Content and Language Integrated Learning (CLIL) Project: Opportunities and challenges in the context of heritage language education. Proceedings of The European Conference on Language Learning Official Conference.

Chilingaryan, K. \& Gorbatenko, R. (2015). Motivation in language learning. RUDN University. Proceedings of Education Conference. Retrieved from https://repository.rudn.ru/en/records/article/record/8363/

Coyle, D., Hood, P. \& Marsh, D. (2010). Content and Language Integrated Learning. Cambridge: Cambridge University Press.

Coyle, D., Hood, P., \& Marsh, D. (2010). CLIL: Content and Language Integrated learning. Cambridge: Cambridge University Press.

Cross , R. \& Gearon, M. (2013). Research and Evaluation of the content and language integrated learning (CLIL) approach to teaching and learning languages in Victorian schools. Retrieved from: https://www.education.vic.gov.au/Documents/school/teachers/teachingresources/disciplin e/languages/CLILtrialresearchrpt.pdf

Czura, A. \& Kołodyńska, A. (2015). CLIL instruction and oral communicative competence in a primary school setting. Cross-Cultural Perspectives on Bilingualism and Bilingual Education, 88-117.

Darn, S. (2015). Content and language integrated learning (CLIL): An European overview Retrieved from: https://eric.ed.gov/?id=ED490775

Delliou, A.\& Zafiri,M. (2016).Developing the speaking skills of students through CLIL: A case of sixth grade primary school students in Greece. The 5th Electronic International Interdisciplinary Conference. Retrieved from https://www.researchgate.net/publication/308194120

Diab, A. M. (2018). Using the Content and Language Integrated Learning (CLIL) Approach to Develop Student Teachers' EFL Receptive Skills. Unpublished Ph.d. Dissertation. Faculty of Education, Benha University.

Escobar, U. C. (2019). An introduction to content and language integrated learning (CLIL) for teachers and teacher Educators. CLIL Journal of Innovation and Research in Plurilingual and Pluricultural Education, 2(1), 7-19. Dol: https://doi.org/10.5565/rev/clil.21.

Gil, M. G. (2010). Content and language Integrated learning (CLIL) in Compulsory Secondary Education. A Case Study in a State High School in Majorca. Ph.d. Dissertation. University of the Balearic Islands (UIB). 
Hadfield , J. \& Dornyei, Z. (2014). Motivating Learning. New York: Routledge.

Harrop, E. (2012). Content and Language Integrated Learning (CLIL) Limitations and Possibilities. Encuentro, 21 ( 57-70).

Hui , L. (2011). Improving Students' English Speaking Skill through Contest - Based Instruction. Unpuldished M.A. Thesis. Sebelas Maret University, Surakarta.

Imane, K. K. (2016). Enhancing EFL Learners' Speaking Skill through Effective Communicative Activities and Strategies. The Case of First Year EFL Students. Unpublished M.A. Theses. Faculty of Letters and languages. Tlemcen University.

Juniardi,Y., Herlina,L., Lubis, A. \& Pahamzah, J. (2020). Computer- vs. Mobile-Assisted Learning to Promote EFL Students Speaking Skills: A Preliminary Classroom-Based Research. International Journal of Instruction, 13(3), 417-432.

Kurum, E. Y. (2016). Teaching speaking skills. In A.P .Solak, Teaching Language Skills for Prospective English Teachers. Turkey: Pelikan Yayinlari.

Laksana, A.J. (2016). The Effectiveness of Using Chain Story Game in Teaching Speaking (An Experimental Research at the Eight Grade Students of SMP Negeri 1 Jatilawang in the Academic Year 2015-2016). Unpublished Ph.d. Dissertation. Universitas Muhammadlyah Purwokerto.

Lasagabaster, D. \& Sierra, J. (2009). Language attitudes in CLIL and traditional EFL classes. International CLIL Research Journal, 1(2), 4-16.

Manurung, K. (2015). Improving the speaking skills using reading contextual internetbased instructional materials in an EFL class in Indonesia. Procedia- Social and Behavioral Sciences, 176, 44-51.

McDougald, J. (2015). Teachers' attitudes, perceptions and experiences in CLIL : A look at content and language, Colombian Applied Linguistic Journal,17(1), 25-41.

Mede, E. \& Çinar, S. (2018). Implementation of content and language integrated learning and its effects on student motivation. LACLIL, 11(2), 215-235. DOI: 10.5294/lacli1.2018.11.2.3

Mohamed, H. M. (2019). Using Dogme in ELT to develop student teachers' speaking skills and their self-efficacy. Journal of Research in Curriculum, Instruction and Educational Technology (JRCIET),5(3),163-186.

Oradee, T. (2012). Developing speaking skills using three communicative activities (discussion, Problem- solving, and role play). International Journal of Social Science and Humanity, 2 (6), 533-535. 
Pakula, H. (2019). Teaching Speaking. Apples - Journal of Applied Language Studies, 13 (1), 95-111.

Papaja, K. \& Rojczyk, A. (2013). Motivation from the perspective of a CLIL teenage learner in D. Gabrys-Barker and J. Bielska (eds): The Affective Dimension in Second Language Acquisition. England :Multilingual Matters.

Rao, P.S. ( 2019) . The importance of speaking skills in English classrooms. Alford council of International English \& Literature Journal (ACIELJ), 2 (2), 6- 18.

Sabra, I. M. (2017). A Proposed Program Based on Content and Language Integrated Learning (CLIL) Approach to Develop some History Section Students' Language Skills. Unpublished M.A. Thesis. Faculty of Education, Hurghada University.

Safitri, H. , Rafli, Z., \& Dewanti, R. (2020). Improving Students' Speaking Skills through Task-Based Learning: An Action Research at the English Department. International Journal of Multicultural and Multireligious Understanding (IJMMU),7(6),88-99.

Saheb , V. (2014) . Motivation in English as a foreign language learning: A study of motivation toward English language learning in Stockholm's upper secondary schools for adults (KOMVUX). $\quad$ Retrieved from https://www.divaportal.org/smash/record.jsf?pid=diva2\%3A782288\&dswid=1447

Sayin, B.A. (2015). Considerations on speaking skills: Essence of learning and teaching speaking. Sino-US English teaching, 12 (11), 827 - 834.

Sulistova, J. (2013). The content and language integrated learning approach in use. Acta Technologica Dubnicae, 3 (2), 47-54. DOI: 10.1515/atd-2015-0018.

Tohidi, H. \& Jabbari, M. (2012). The effects of motivation in education. Procedia- Social and Behavioral Sciences, 31, $820-824$

Turabik, T. \& Baskan, G. (2015). The importance of motivation theories in terms of education systems. Procedia-Social and Behavioral Science, 186, 1055- 1063. 
استخدام التعلم القائم على دمج اللغة بالمحتوى لتنمية مهارات التحدث باللغة الإنجليزية والدافعية للتعلم

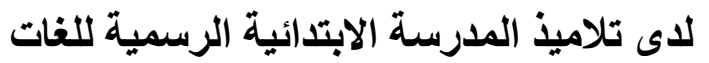

د. مروة مراد صالح

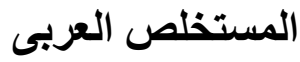

هدفت الدر اسة الحالية إلى تتمية مهار ات التحدث و الدافعيـة للتعلم لدى تلاميذ المدرسـة الابتدائيـة الرسمية

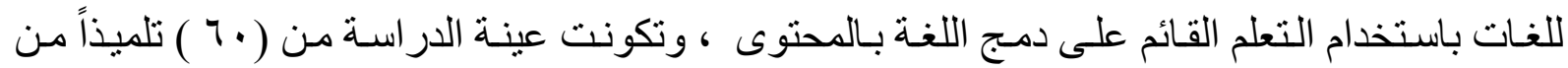

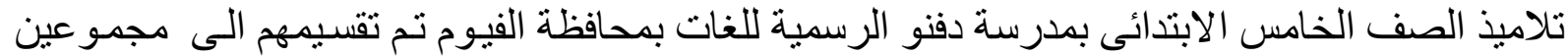

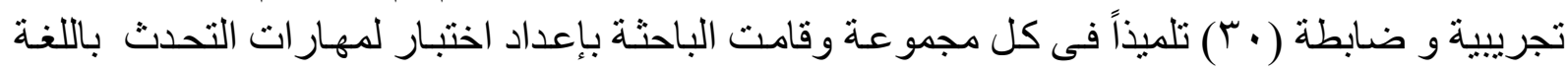

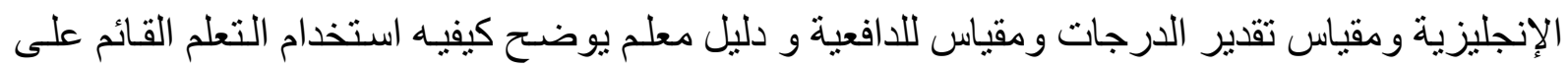
دمج اللغة بالمحتوى فى تنمية مهارة التحدث و الدافعية وبعد تطبيق اختبار التحدث ومقئ ومياس الدافعية للتعلم

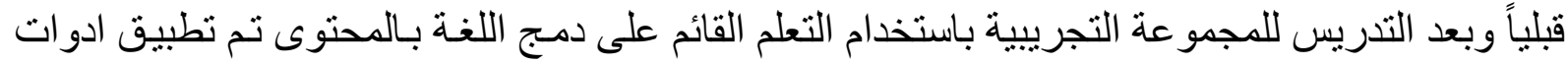

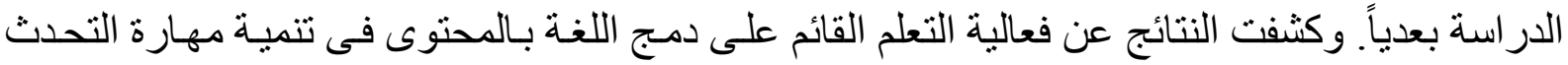
باللغة الإنجليزية والدافعية للتعلم لدى أفر اد العينة. و اختتمت الباحثة الدر اسة بتقديم مجمو عة من التوصيات التى تفيد التلاميذ و المعلمين و الموجهين هذا بالإضـافة إلى اقتر اح بعض الدر اسات والبحوث المستقبلية.

الكلمات المفتاحية: التعلم القائم على دمج اللغة بالمحتوى ـ مهار ات التحدث ب باللغـة الإنجليزيـة ـ الدافعيـة للتعلم- تلاميذ المدرسة الابتدائية الرسمية للغات المعات 